\title{
Cycads in vitro
}

\section{Jaime A. Teixeira da Silva, Wynston Ray Woodenberg ${ }^{1}$ and Songjun Zeng ${ }^{2}$}

\author{
P. O. Box 7, Miki-cho post office, Ikenobe 3011-2, Kagawa-ken, 761-0799, Japan
}

Key words: Cycas revolute, Mature zygotic embryo, Plant growth regulator

\begin{abstract}
The Cycadales are a group of botanical and evolutionary importance; however, many species face the threat of extinction due to poaching and habitat destruction. The current investigation reviews previous work on in vitro production of cycads, which holds great potential for mass production and germplasm conservation of these unique plants. Megagametophytes and zygotic embryos have been used as explants in most studies, while seedling tissue and new leaf tissue of mature trees have also been used. Callus, coralloid roots and somatic embryos have been formed in vitro but direct organogenesis appears to be the most promising method for mass production and germplasm preservation of the cycads, as recent studies have reported the acclimatization of numerous plantlets less than 200 days after initial culture of zygotic embryos.

Cycads have been referred to by Gilbert (1984) as "living fossils" because they are an ancient group of plants, the Cycadales being the oldest of the living members of the gymnosperms (Ikeno 1896) and are therefore an important group in the quest to unravel the mysteries of plant evolution.

Cycads are made up of three families: Cycadaceae, Stangeriaceae and Zamiaceae (Chavez et al. 1998). In the Cycadales, Hill and Stevenson (1999) listed 273 tropical and subtropical species in 11 genera although Chavez et al. (1998) claim 132 species in 10 living families. Cycas revoluta Thunb., commonly known as "Japanese sago palm", is probably the most researched member of the Cycadaceae family and is the oldest of the living cycads (Jones 1993). Native to southern China and Japan (Stevenson 1990), it has several characteristic botanical features: it is evergreen, has palm-like, pinnately divided, glossy green leaves
\end{abstract}

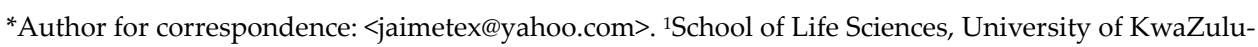
Natal (Westville Campus), Durban 4001, South Africa. < wnstnwdnbrg@gmail.com>. ${ }^{2}$ Key Laboratory of Plant Resources Conservation and Sustainable Utilization, South China Botanical Garden, Chinese Academy of Sciences, Guangzhou 510650, China. <Zengsongjun@scib.ac.cn>. 
with narrow leaflets that have a sunken midrib and rolled down margins (Gilman 1999). In addition to its ornamental value, C. revoluta has some medicinal properties such as the traditional treatment of cancer (Kowalska et al. 1995) and nutritional value, including eaten raw, cooked, or in a fermented state within "miso" soup (Brenner et al. 2003), but with toxic potential (Chang 2004), possibly due to the presence of cycasin (Tadera et al. 1995). In its ornamental appeal, reputed medicinal properties, nutritional value and toxicity, C. revoluta epitomizes the economic importance of cycads.

Cycads are also unique in their possession of motile antherozoids and are the only gymnosperms that have a symbiotic relationship with nitrogen-fixing cyanobacteria (Vessey et al. 2005), which inhabit specialized branching structures of cycads known as apogeotropic or coralloid roots (Webb et al. 1984, Lindblad and Bergman 1990, Korzhenevskaya et al. 1999, Vessey et al. 2005). Cycads of today, however, represent a small fraction of a plant group that once dominated the earth's flora millions of years ago (Bhatnagar and Moitra 1996), and many species now face the threat of extinction in the wild.

While cycad numbers appear to have declined naturally over the millennia, the principal reasons for their rapid decline in recent years include the removal of plants from the wild by collectors, traders and landscapers, and the destruction of habitat for agricultural, domestic and commercial development (Osborne 1995; Donaldson et al. 2003; Vovides et al. 2003). Cycad numbers have declined to such an extent that all species are now included in either Appendix I or II of the Convention in International Trade in Endangered Species of Flora and Fauna (CITES 2014), and are protected by law in various countries. However, despite legislative protection for a number of years, there has not been a substantial increase in cycad numbers in the wild mainly due to reproductive failure, as a very few seeds germinate in nature and few seedlings are observed (Forsyth and van Staden 1983, Giddy 1990).

Cycads are dioecious with males bearing cones and females bearing groups of megasporophylls (Ikeno 1896). It is, therefore essential that male and female plants of the same species cone at the same time for fertilized seed to be produced in nature, which may present a problem in populations with a few individuals. Although a few studies have been conducted, cycad seeds also appear to be recalcitrant (Dehgan and Schutzman 1989, Forsyth and van Staden 1983, Woodenberg et al. 2010), i.e. they are 'wet' and desiccation-sensitive, and may succumb to dehydration in the field during the protracted development of the embryo after seed-shed (Woodenberg et al. 2014). While rapid germination (2-6 weeks) of Zamia floridana (sensu lato) seeds is possible when the sarcotesta is removed and seeds are soaked in $\mathrm{H}_{2} \mathrm{SO}_{4}$ for $1 \mathrm{hr}$, rinsed, then soaked in $1 \mathrm{~g} / 1 \mathrm{GA} 3$ 
for 48 hrs (Dehgan and Johnson 1948), C. revoluta seeds lose viability rapidly and have low morphogenic potential or recalcitrance in vitro (Benson 2000). The recalcitrant nature of cycad seeds means that they are not suitable for ex situ long term storage and/or conservation and therefore methods - other than seed propagation - are urgently needed to conserve these plants.

Furthermore, cycads are generally slow growers and it may take up to 15 years for a seedling to become sexually mature (Norstog and Nicholls 1997, Tang 1990, Vogel et al. 1995). Hence, cycad numbers in the field increase naturally at a relatively slow rate and there is a pressing need to develop effective biotechnological protocols for the mass production of cycads to satisfy the demand by landscapers and collectors, and to prevent the extinction of these ancient plants.

In this regard, the current review aims to analyze the in vitro studies that have been conducted on members of the Cycadales, since biotechnology specifically tissue culture - is a viable way to conserve the germplasm of this ancient plant group (Litz et al. 2004, 2005).

The first in vitro studies on cycads (Gymnospermae, Cycadales) was reported by La Rue $(1948,1954)$ for Zamia floridana (= pumila) (Zamiaceae) and Norstog (1965) for Zamia integrifolia. Callus induction from zygotic embryos (ZEs) and/or megagametophytes of Cycas circinalis and Zamia integrifolius was reported by Norstog and Rhamstine (1967), of Zamia pumila by Webb et al. (1983), and of Dioon edule by Chavez and Litz (1999). De Luca et al. (1979) conducted studies on the in vitro culture of Ceratozamia mexicana, C. revoluta and Encephalartos umbeluziensis megagametophytes and identified structures that were classified as pseudobulbils or globular embryos but that were later corrected in C. revoluta to coralloid root nodules (De Luca and Sabato 1980, De Luca et al. 1980) and by Webb and Osborne (1988) as adventitious shoots in Ceratozamia mexicana. Chavez et al. (1992a, 1995) then reported somatic embryogenesis from the leaves of $C$. mexicana while somatic embryogenesis and shoot formation were reported in $C$. mexicana and $C$. hildae when ZEs and megagametophytes were used (Chavez et al. 1992b). In those studies, somatic embryos developed within $2-4$ months and reached the cotyledonary stage after $6-8$ months (18 months for leaves) in culture. Chavez et al. (1995) criticized how earlier claims of somatic embryogenesis were not substantiated by sufficient histological proof, and also indicate how somatic embryogenesis in C. mexicana differed substantially (dicotyledonous in nature when from leaves) from the in ovulo development of ZEs as defined by Chamberlain (1912) (monocotyledonous in nature), although Dorety (1908) claimed a dicotyledonous-like development of excised Ceratozamia ZEs. 
Following a suitable explant disinfection process (Table 1), in most studies, it was common to induce callus from ZEs or megagametophytes using kinetin or 2,4-D, BA and NAA (La Rue 1950, 1954, Webb et al. 1983, Pan et al. 2013), and more recently one case of the use of picloram for callus induction (Ling et al. 2008) (Table 1). Webb et al. (1983) reported that NAA was required for callus initiation, but BA was not always necessary. High frequency of callus initiation occurred with $1.0 \mathrm{mg} / \mathrm{l}$ NAA combined with 0.01 or $1.0 \mathrm{mg} / \mathrm{l} \mathrm{BA}$. When the concentration of NAA was high relative to that of BA, friable callus formed and as the relative $\mathrm{BA}$ concentration was increased, a more compact callus formed. Compact-nodular callus developed at equal concentrations of NAA and BA over a wide range of absolute concentrations. Friable callus formed roots only while compact-nodular callus formed roots, shoots and ZE-like structures. Dhirnan et al. (1998) reported callus formation from the leaves of C. revoluta.

The sterilization procedure employed by several authors is quite similar (Table 1). However, Chaplot and Jasrai (2000) used bulbils as explants and a complicated sterilization procedure. Bulbils were treated for $90 \mathrm{~min}$ with an aqueous solution containing $0.1 \%$ bavistin, $0.1 \%$ citric acid, $1 \%$ activated charcoal on a gyratory shaker $(100 \mathrm{rpm})$, and surface sterilized with $50 \%$ ethanol for $1 \mathrm{~min}$, followed by $0.1 \% \mathrm{HgCl}_{2}$ for $3 \mathrm{~min}$. The outer 9 or 10 bulb-scales were discarded and the bulbils were re-treated with $0.05 \% \mathrm{HgCl}_{2}$ for $1 \mathrm{~min}$, followed by repeated rinses with sterile distilled water five times. The inner $(8-10)$ bulb-scales were used as explants. After incubation for 20 - 25 days, shoot primordia differentiated in $60 \%$ of the cultures of only the inner bulb-scales on half-strength MS with 2.21 $\mu \mathrm{M}$ BA. One or two shoot buds differentiated directly on either surface of the bulb-scale without any observable callus formation. Three weeks after culture the explants bearing shoot buds were transferred to fresh medium. At $4.43 \mu \mathrm{M}$ BA there was slight callus formation. However, the callus failed to differentiate further, even on fresh medium. The choice of gelling agent (Moon et al. 2004) or light intensity (Vargas-Luna et al. 2004) can affect the qualitative and quantitative outcome of somatic embryogenesis. Some parallels have been drawn between somatic embryogenesis of coniferous gymnosperms and cycads, the former having been reviewed elsewhere (Teixeira da Silva and Malabadi 2012).

Luo et al. (2011) reported the formation of callus from root tips or the stem of in vitro seedlings of Cycas guizhouensis on MS containing $50 \mathrm{mg} / \mathrm{l} \mathrm{Kn}$ and $20 \mathrm{mg} / \mathrm{l}$ 2,4-D or MS with $50 \mathrm{mg} / \mathrm{l} \mathrm{Kn}$ and $20 \mathrm{mg} / \mathrm{l} \mathrm{BA}$. There are no other reports about callus proliferation or plant regeneration for this plant. 


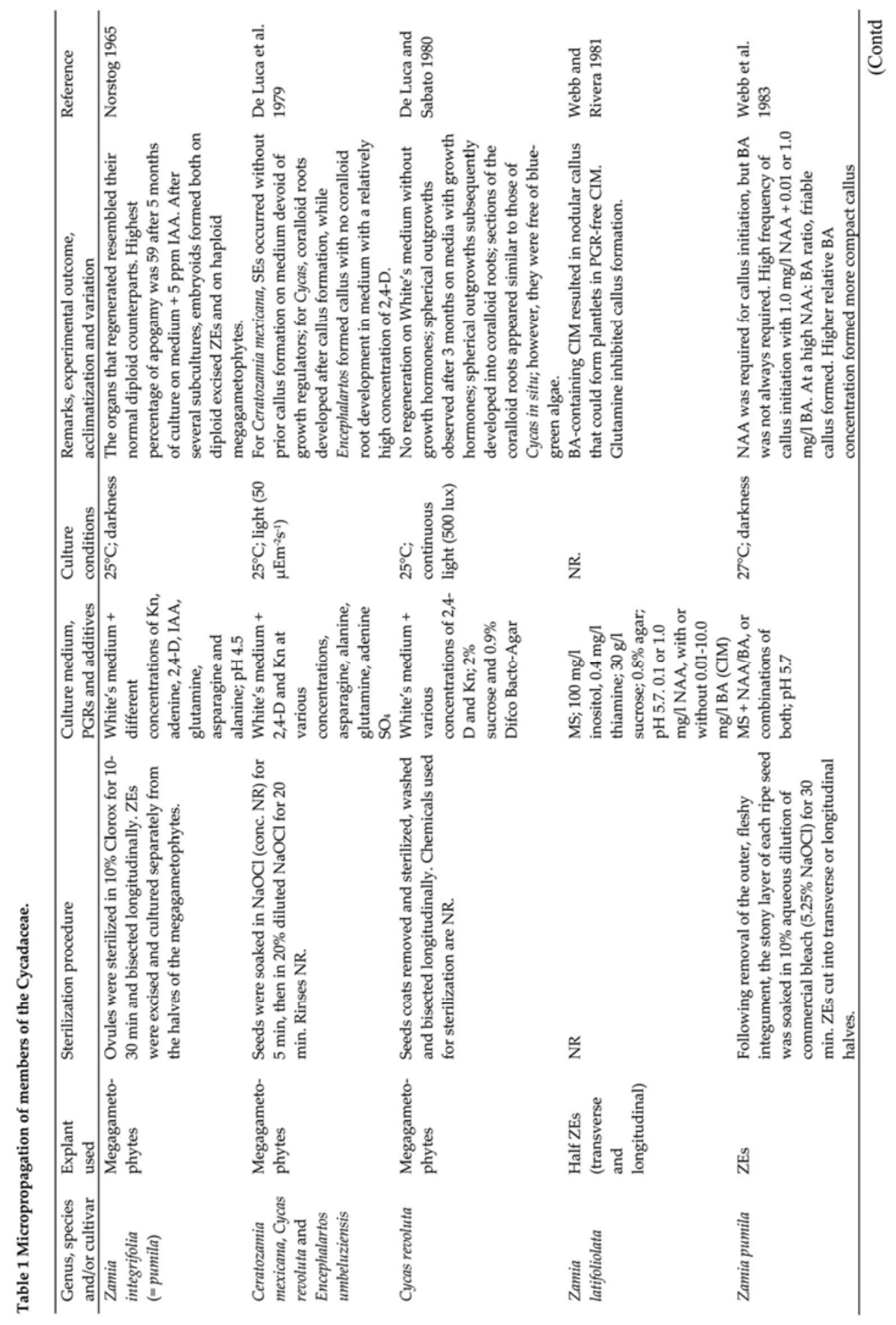




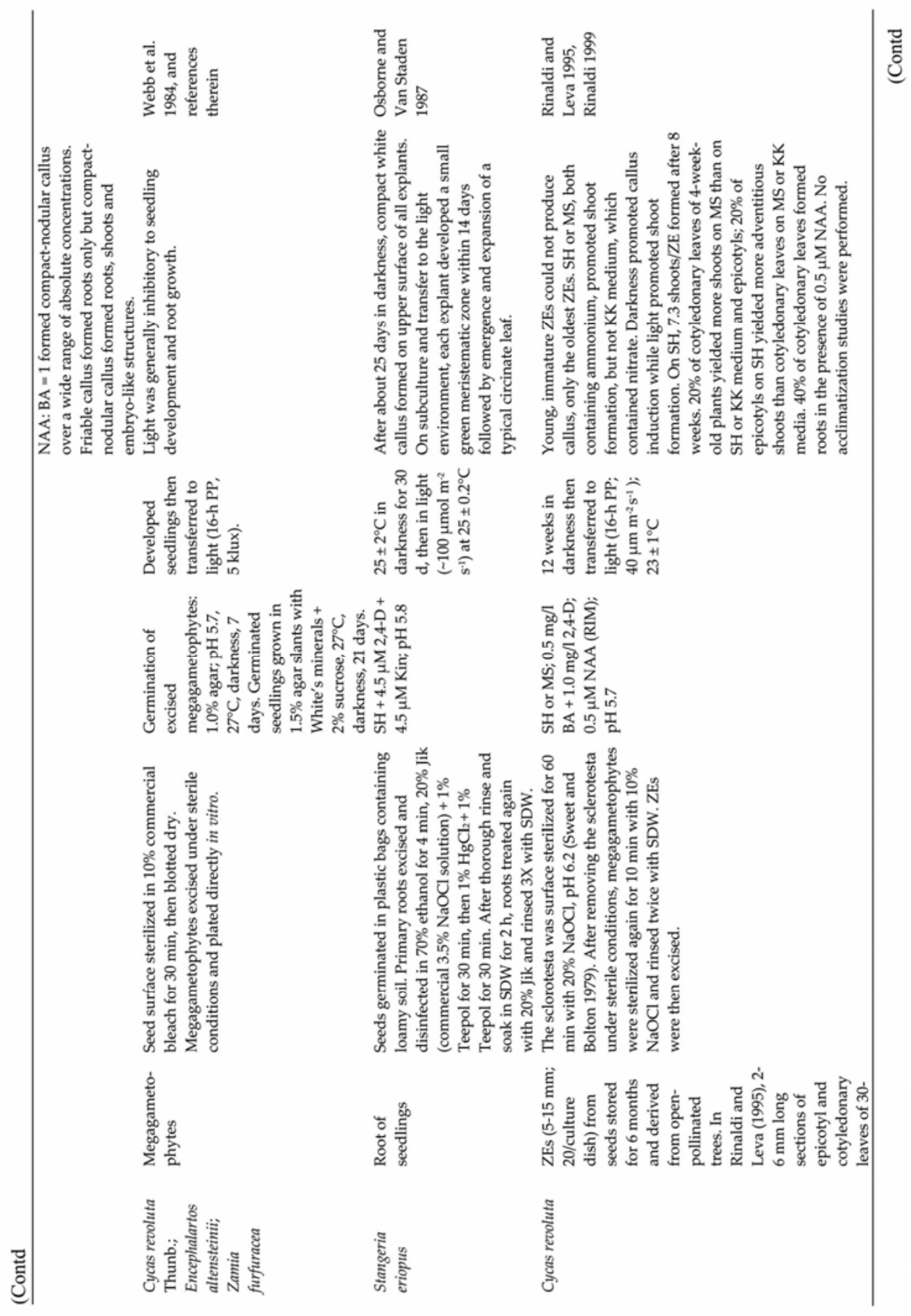




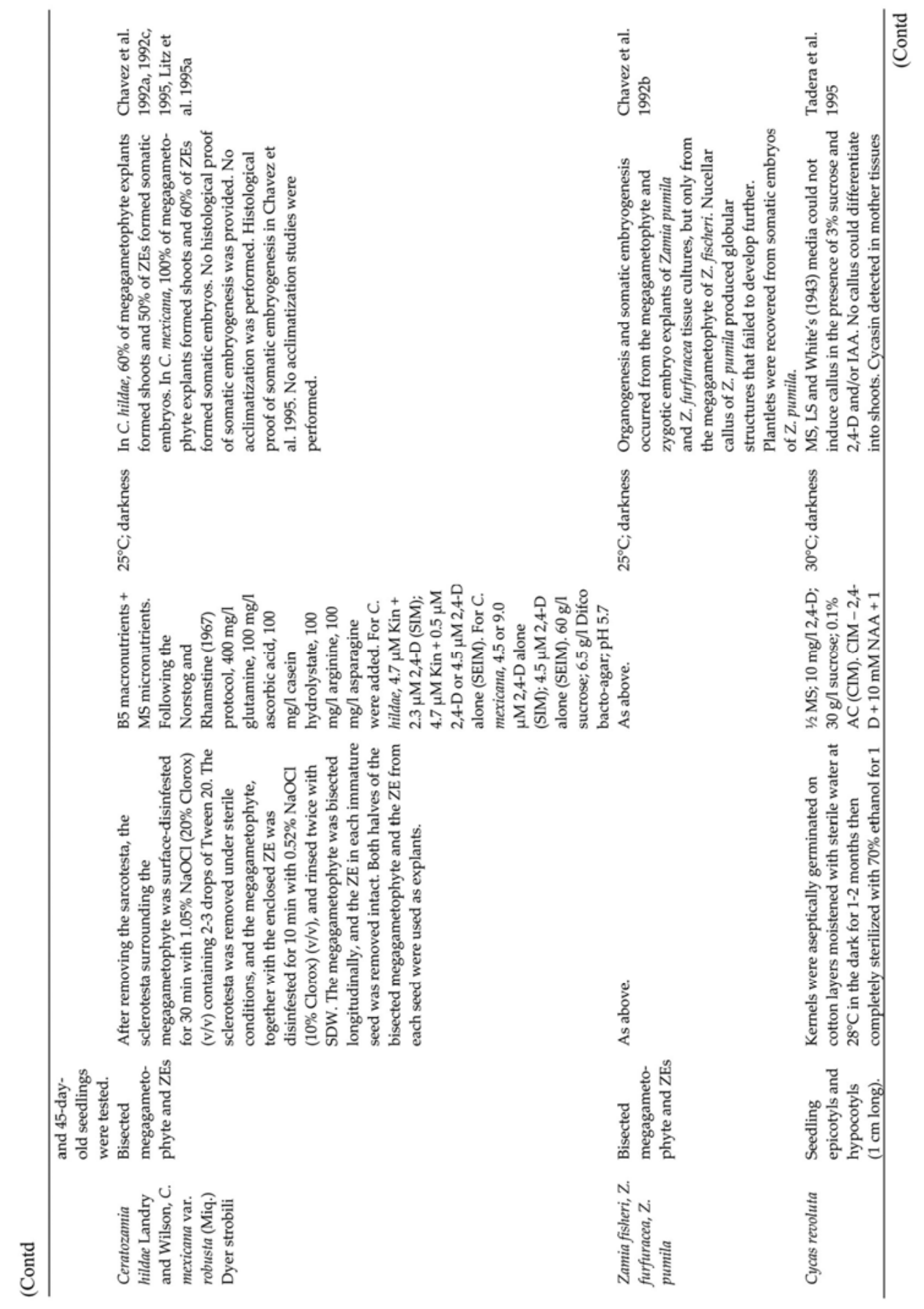




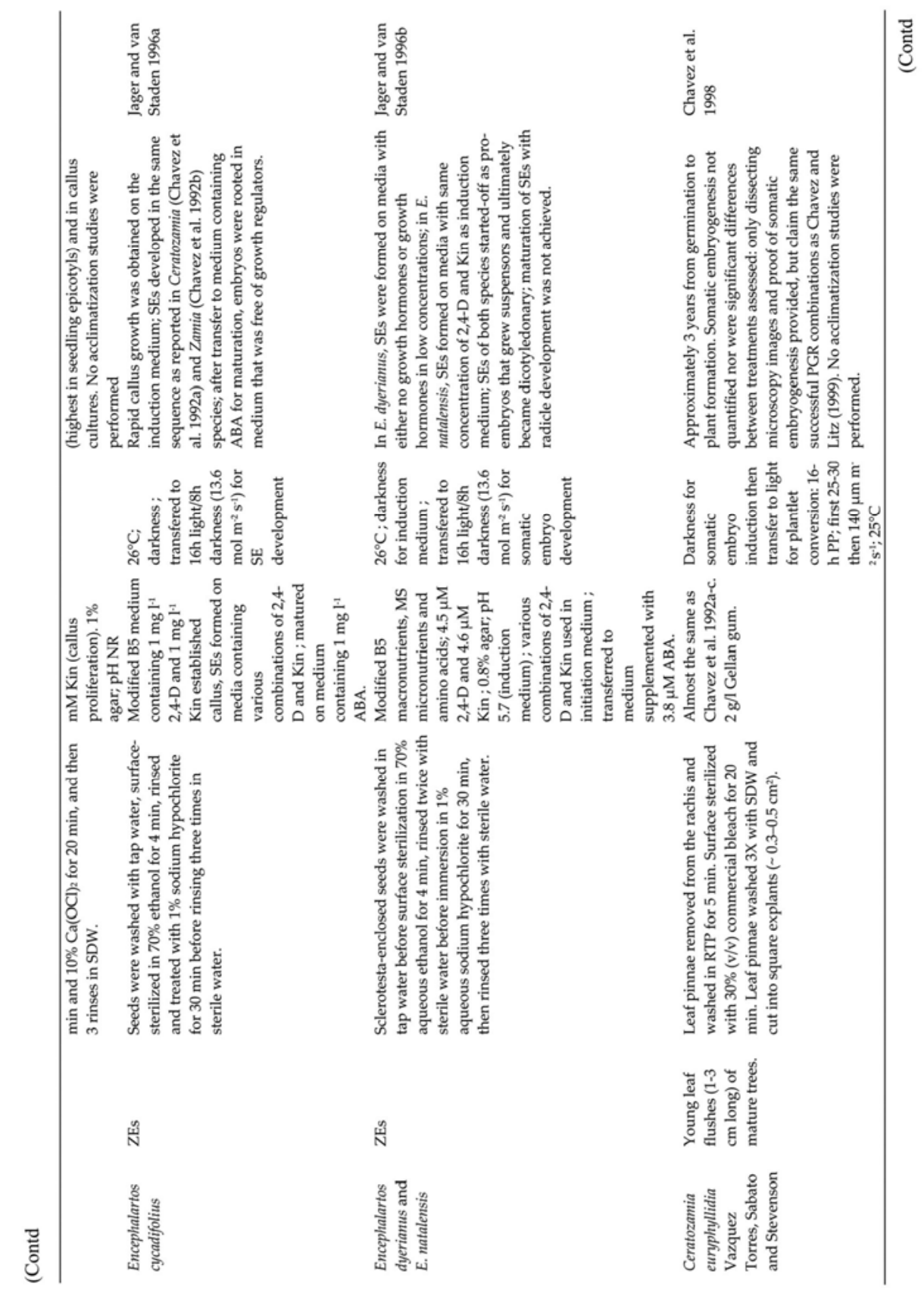




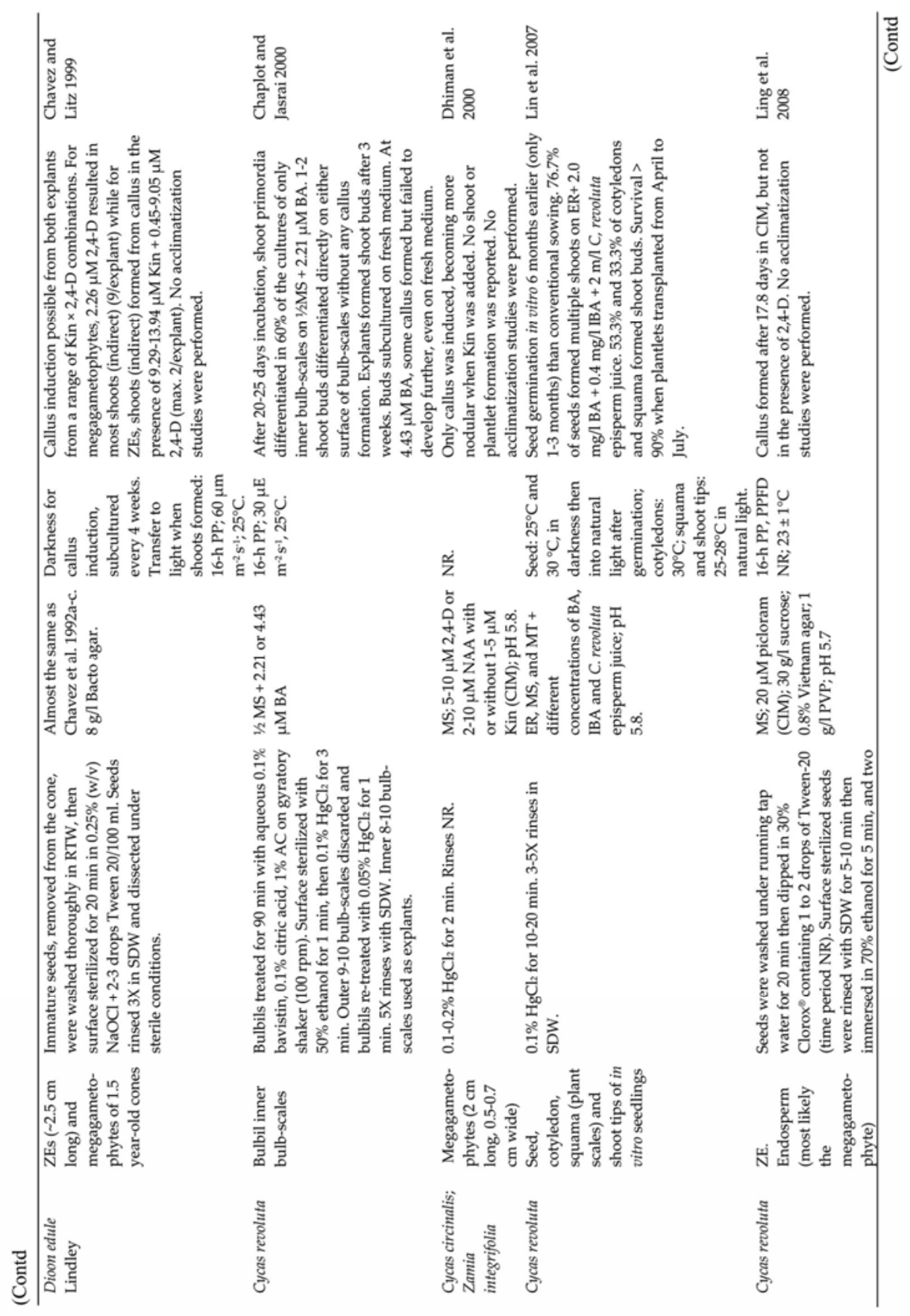




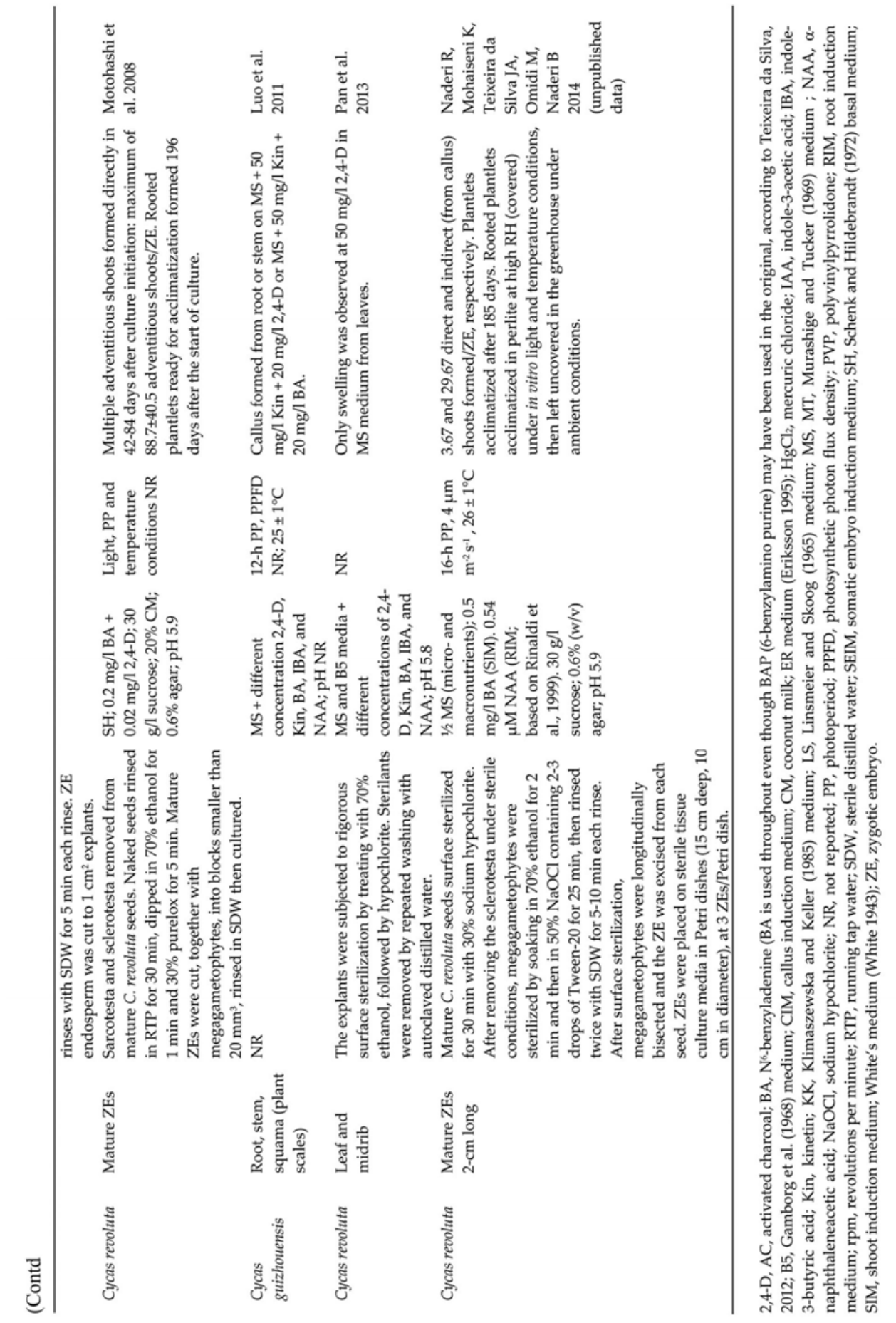


Lin et al. (2007) reported plantlet regeneration in vitro, particularly the formation of multiple shoots derived from seed, cotyledon, squama (plant scales) and shoot tips of $C$. revoluta. C. revoluta seed cultured in vitro could germinate six months earlier than when sown under normal conditions (ex vitro) at $25^{\circ} \mathrm{C}$. When seeds were inoculated on ER media (Eriksson 1995) containing $2.0 \mathrm{mg} / \mathrm{l} \mathrm{BA}, 0.4$ $\mathrm{mg} / \mathrm{l} \mathrm{IBA}$, and $2 \mathrm{ml} / \mathrm{l}$ of juice of $C$. revoluta episperm (testa), multiple shoots formed on $76.7 \%$ of explants. Shoot buds differentiated from $53.3 \%$ of cotyledons and from $33.3 \%$ of squama. Survival rate exceeded $90 \%$ when plantlets were transplanted from April to July on a substrate of sand and garden soil, or a $1: 1$ $(\mathrm{v} / \mathrm{v})$ mixture of perlite and coco coir.

An effective in vitro protocol serves several purposes for cycads: (1) to conserve rare or endangered germplasm; (2) to establish protocols that will allow for the clonal production of standardized material, suitable for gardening; (3) with standardized protocols, aspects such as gametogenesis can be examined without the dependence on environmental cues and tissues subjected to genetic transformation can have a better chance of recovery of transgenic callus, plantlets or somatic embryos; (4) the ability to obtain regenerable transformants would allow for the introduction of novel traits such as disease or pest resistance; (5) the ability to induce somatic embryos would allow for the mass production of plantlets through bioreactor culture; (6) in vitro production of algae-free coralloid roots may be important for studies on cycad-cyanobacteria symbiosis - especially studies looking at the path of entry of cyanobacteria; and (7) to produce suitablysized explants for the cryopreservation of these endangered plants.

\section{Acknowledgements}

The authors thank Judit Dobránszki (Research Institute of Nyíregyháza, Hungary) for providing some essential, difficult-to-access literature.

\section{Conflicts of interest}

The authors declare no conflicts of interest.

\section{References}

Benson EE (2000) In vitro plant recalcitrance in vitro plant recalcitrance: An introduction. In Vitro Cell. Dev. Biol. - Plant 36: 141-148.

Bhatnagar SP and Moitra A (1996) Gymnosperms. New Age International Limited, New Delhi.

Brenner ED, Stevenson DW and Twigg RW (2003) Cycads: evolutionary innovations and the role of plant-derived neurotoxins. Trends Plant Sci. 8: 446-452.

Chamberlain CJ (1910) Morphology of Ceratozamia. Bot. Gaz. 53: 1-18. 
Chang SS (2004) Acute cycas seed poisoning in Taiwan. J. Toxicol. Clin. Toxicol. 42: 11191126.

Chaplot BB and Jasrai YT (2000) Differentiation of shoot buds in bulb-scale cultures of Cycas revoluta Thunb. Phytomorphology 50: 37-40.

Chávez VM and Litz RE (1999) Organogenesis from megagametophyte and zygotic embryo explants of the gymnosperm Dioon edule Lindley (Zamiaceae, Cycadales). Plant Cell Tiss. Org. Cult. 58: 219-222.

Chávez VM, Litz RE and Marquez J (1995) Histology of somatic embryogenesis of the cycad Ceratozamia mexicana var. Robusta (Miq.) Dyer. Plant Sci. 108: 191-200.

Chávez VM, Litz RE, Monroy M, Moon PA and Vovides AM (1998) Regeneration of Ceratozamia euryphyllidia (Cycadales, Gymnospermae) plants from embryogenic leaf cultures derived from mature-phase trees. Plant Cell Rep. 17: 612-616.

Chávez VM, Litz RE and Norstog K (1992a) In vitro morphogenesis of Ceratozamia hildae and C. mexicana from megagametophytes and zygotic embryos. Plant Cell Tiss. Org. Cult. 30: 93-98.

Chávez VM, Litz RE and Norstog K (1992b) Somatic embryogenesis and organogenesis in Zamia fisheri, Z. furfuracea and Z. pumila. Plant Cell Tiss. Org. Cult. 30: 99-105.

Chávez VM, Litz RE, Moon PA and Norstog K (1992c) Somatic embryogenesis from leaf callus of a mature gymnosperm Ceratozamia mexicana var Robusta (Miq.) Dyer (Cycadales). In Vitro Cell. Dev. Biol. - Plant 28: 59-63.

CITES (Convention in International Trade in Endangered Species of Flora and Fauna) (2014) http://www.cites.org/eng/app/appendices.php. Last accessed: 3 January, 2015

Dehgan B and Johnson CR (1983) Improved seed germination of Zamia floridana (sensu lato) with $\mathrm{H}_{2} \mathrm{SO}_{4}$ and $\mathrm{GA}_{3}$. Sci. Hortic. 19: 357-361.

Dhirnan M, Moitra S, Singh MN and Bhatnagar SP (1998) In vitro studies on some nonconiferous gymnosperms. Curr. Sci. 75: 1113-1115.

De Luca P, Moretti A and Sabato S (1979) Regeneration in megagametophytes of cycads. Giorn. Bot. Ital. 113: 129-143.

De Luca P and Sabato S (1980) Regeneration of coralloid roots on cycad megagametophytes. Plant Sci. Lett. 18: 27-31.

Dhiman M, Moitra S, Singh MN and Bhatnagar SP (2000) Organogenesis in female gametophyte and embryo cultures of cycads: Cycas circinalis and Zamia integrifolia. J. Plant Biochem. Biotechnol. 9: 111-113.

Donaldson JS, Hill KD and Stevenson DW (2003) Cycads of the World: An Overview. In: Donaldson JS (ed) Cycads. IUCN - The World Conservation Union. Charlesworth \& Co Ltd., Huddersfield, UK, pp 3-8.

Dorety HA (1908) The embryo of Ceratozamia. Bot. Gaz. 45: 412-416.

Dyer RA (1965) The cycads of Southern Africa. Bothalia 8: 405-514.

Gamborg OL, Miller RA and Ojima K (1968) Nutrient requirements of suspension cultures of soybean root cells. Exp. Cell Res. 50: 151-158.

Gilbert S (1984) Cycads: Status, Trade, Exploitation and Protection 1977-1982. World Wildlife Fund, Washington, DC, USA. 
Gilman EF (1999) Cycas revoluta: General information and description. Review paper of Institute of Food and Agriculture Sciences. Environment Horticulture Department, Florida.

Hill KD and Stevenson DW (1999) The cycad pages. World list of cycads. http://plantnet.rbgsyd.gov.au/PlantNet/cycad/wlist.html. Last accessed: 3 January, 2015

Ikeno S (1896) Das Spermatozoid von Cycas revoluta. Bot. Mag. (Tokyo) 10: 367-368.

Jager AK and van Staden J (1996a) Somatic embryogenesis in Encephalartos cycadifolius. Plant Cell Rep. 15: 437-440.

Jager AK and van Staden J (1996b) Somatic embryogenesis and organogenesis in Encephalartos dyerianus and E. natalensis. Plant Cell Tiss. Org. Cult. 45: 99-102.

Jager AK and van Staden J (1999) Somatic embryogenesis in African cycads (Encephalartos). In: Mohan Jain S. et al. (eds.) Somatic Embryogenesis in Woody Plants, Volume 4, Kluwer Academic Publishers, pp. 449-460.

Jones DL (1993) Cycads of the World. Reed Book, New York Bot Gardens, Chatswood. pp. 312.

Klimaszewska K and Keller WA (1985) High frequency plant regeneration from thin cell layer explants of Brassica napus. Plant Cell Tiss. Org. Cult. 4: 183-197.

Korzhenevskaya TG, Lobakova ES, Dol'nikova GA and Gusev MV (1999) Peculiarities of microsymbiont topography in apogeotropic roots of Cycas revoluta and Encephalartos horridus. Mikrobiologiya 68: 33-38.

Kowalska MT, Itzhak Y and Puett D (1995) Presence of aromatase inhibitors in cycads. J. Ethnopharmocol. 47(3): 113-116.

La Rue CD (1948) Regeneration in the gametophyte of Zamia floridana. Bull. Torrey Bot. Club 75: 597-603.

La Rue CD (1950) Regeneration in cycads. Am. J. Bot. 37: 664.

La Rue CD (1954) Studies on growth and regeneration in gametophytes and sporophytes of gymnosperms. Brookhaven Symp. Biol. 6: 187-208.

Lin QL, Shi RB, Lin YC, Lin XB, Gong JC and Zou N (2007) Plantlets with multi-shoots of Cycas revoluta Thunb. in vitro. Acta Hortic. Sin. 37(6): 1575-1578.

Lindblad P and Bergman B (1990) The cycad-cyanobacterial symbiosis. In: Rai AN (ed) Handbook of Symbiotic Cyanobacteria, Boca Raton: CRC Press, pp. 137-159.

Ling PKA, Thing YS, Gansau JA and Hussein S (2008) Induction and multiplication of callus from endosperm of Cycas revoluta. African J. Biotechnol. 7: 4279-4284.

Linsmaier EM and Skoog F (1965) Organic growth factor requirements of tobacco tissue cultures. Physiol. Plant. 18: 100-127.

Litz RE, Moon PA, Benson EM, Stewart J and Chávez VM (2004) A biotechnology strategy for medium- and long-term conservation of cycads. Bot. Rev. 70: 39-46.

Litz RE, Moon PA and Chávez VM (1995) Somatic embryogenesis from leaf callus derived from mature trees of the cycad Ceratozamia hildae (Gymnospermae). Plant Cell Tiss. Org. Cult. 40: 25-31.

Litz RE, Moon PA and Chávez VM (2005) Somatic embryogenesis and regeneration of endangered cycad species. Acta Hortic. (ISHS) 692: 75-79. 
Lobakova ES, Dubravina GA and Zagoskina NV (2004) Formation of phenolic compounds in apogeotropic roots of cycad plants. Russian J. Plant Physiol. 51(4): 486493.

Luo ZQ, Wang LH, Li WJ and Zhu J (2011) Study on tissue culture of Guizhou Cycas guizhouensis L. J. Anhui Agric. Sci. 39(2): 859-886.

Moon PA, Litz RE and Chávez VM (2004) Effect of gelling agent on growth and development of Ceratozamia hildae somatic embryos. Bot. Rev. 70(1): 47-53.

Motohashi T, Toda M and Kondo K (2008) Adventitious embryo formation derived from zygotic embryos in Cycas revoluta. Plant Biotech. 25: 589-591.

Murashige T and Skoog F (1962) A revised medium for rapid growth and bio assays with tobacco tissue cultures. Physiol. Plant. 15: 473-497.

Murashige T and Tucker DPH (1969) Growth factor requirement of citrus tissue culture. In: Proc. $1^{\text {st }}$ Int. Citrus Symp., University of California, Riverside. 3: 1155-1161.

Norstog K (1965) Induction of apogamy in megagametophytes of Zamia integrifolia. Amer. J. Bot. 52: 993-999.

Norstog K and Rhamstine E (1967) Isolation and culture of haploid and diploid cycad tissues. Phytomorphology 17: 374-381.

Osborne R (1995) An overview of cycad conservation in South Africa. In: Donaldson J (ed) Cycad Conservation in South Africa, Issues, Priorities and Actions. Cycad Society of South Africa, South Africa, pp. 1-7.

Osborne R and van Staden J (1987) In vitro regeneration of Stangeria eriopus. HortSci. 22: 1326.

Pan S, Neeraj A, Srivastava KS, Kishore P and Sarethy IP (2013) Effects of growth regulators on in vitro response and multiple shoot induction in some endangered medicinal plants. OA Biotechnol. 31;2(1): 3 .

Rinaldi LMR (1999) Factors affecting shoot regeneration from zygotic embryo and seedling explants of Cycas revoluta Thunb. In Vitro Cell. Dev. Biol. - Plant 35: 25-28.

Rinaldi LMR and Leva AR (1995) In vitro organogenesis from diploid tissues of Cycas revoluta Thunb. Plant Cell Tiss. Org. Cult. 43: 37-41.

Schenk RU and Hildebrandt AC (1972) Medium and techniques for the induction and growth of monocotyledonous and dicotyledonous plant cell cultures. Can. J. Bot. 50: 199-204.

Stevenson DW (1990) Morphology and systematics of the Cycadales. Mem. N. Y. Bot. Gardens 57: 8-55.

Sweet HC and Bolton WE (1979) The surface decontamination of seeds to produce axenic seedlings. Amer. J. Bot. 66: 692-698.

Tadera K, Gin'ya H, Sawada R, Motani Y, Aikawa Y, Nozaki A, Yagi F and Minami Y (1995) Cycasin formation in tissue cultures of Japanese cycad. Phytochemistry 38: 1199-1201.

Teixeira da Silva JA (2012) Is BA (6-benzyladenine) BAP (6-benzylaminopurine)? Asian Austral. J. Plant Sci. Biotech. 6: 121-124.

Teixeira da Silva JA and Malabadi RB (2012) Somatic embryogenesis in conifers. J. For. Res. 23: 503-515. 
Vargas-Luna I, Ortiz-Montiel G, Chávez VM, Litz RE and Moon PA (2004) Biochemical characterization of developmental stages of cycad somatic embryos. Bot. Rev. 70: 5462.

Vessey JK, Pawlowski K and Bergman B (2005) Root-based N2-fixing symbioses: Legumes, actinorhizal plants, Parasponia sp. and cycads. Plant Soil 274: 51-78.

Vovides AP, Pérez-Farrera MA, Gonzáles-Astorga J, González D, Gregory T, Chemnick J, Iglesias C, Octavio-Aguilar P, Avedaño S and Bárcenas C (2003) An outline of our current knowledge on Mexican cycads (Zamiaceae, Cycadales). Curr. Topics Plant Biol. 4: 159-174.

Webb DT and Osborne R (1988) Cycads. In: Bajaj YPS (Ed) Biotechnology in Agriculture and Forestry Trees 2, Springer-Verlag, Berlin. Pp. 591-613.

Webb DT, Nevarez M and de Jesus S (1984) Further in vitro studies of light-induced root nodulation in the Cycadales. Env. Exp. Bot. 24: 37-44.

Webb DT and Rivera MS (1981) Effects of NAA, BAP and L-glutamine on callus formation and organogenesis of Zamia latifoliolata embryo. Env. Exp. Bot. 21(3-4): 433434.

Webb DT, Rivera ME, Starszak E and Matos J (1983) Callus initiation and organized development from Zamia pumila explants. Ann. Bot. 51: 711-717.

White PM (1943) A Handbook of Plant Tissue Culture, J. Cattell Press, Lancaster, PA.

Woodenberg WR, Berjak P and Pammenter NW (2010) Development of cycad ovules and seeds. 1. Implication of the ER in primary cellularisation of the megagametophyte in Encephalartos natalensis Dyer and Verdoorn. Plant Growth Regul. 62: 265-278.

Woodenberg WR, Berjak P, Pammenter NW and Farrant JM (2014) Development of cycad ovules and seeds. 2. Histological and ultrastructural aspects of ontogeny of the embryo in Encephalartos natalensis (Zamiaceae). Protoplasma 251(4): 797-816. 